\title{
PÓS-GRADUAÇÃO NO EXTERIOR: vale a pena?
}

\author{
Maria do Carmo Friche PASSOS* \\ “...Vivendo se aprende, mas o que se aprende mais \\ é só a fazer outras maiores perguntas..."
} Guimarães Rosa

Se eu tivesse que responder a esta pergunta com apenas uma única palavra escreveria que SIM (com letras maiúsculas), claro que sim, aliás, qualquer experiência de residir e trabalhar fora do país é importante para o profissional. $\mathrm{O}$ contato com outras culturas, o aprendizado em outras universidades e hospitais e, especialmente, o convívio direto com pesquisadores e especialistas renomados têm enorme valor para quem trabalha em um mundo cada vez mais globalizado. Sabemos bem que o médico moderno precisa aguçar seus atributos humanos, adaptar-se a contextos variados e manter a educação permanente.

Para mim foi um grande privilégio poder realizar duas pós-graduações no exterior.

Fiz parte do meu doutorado (bolsa de doutoradosanduíche concedida pelo $\mathrm{CNPq}$ ) na Universidade Autônoma de Barcelona durante todo o ano de 2001. A escola de Barcelona, capitaneada pelos professores Juan Malagelada, Fernando Azpiroz e Jorgi Serra, se dedica, há anos, de forma pioneira, ao estudo da dinâmica dos gases intestinais. No Hospital Vall d'Hebron, sob a orientação desses três pesquisadores realizamos um estudo denominado Resposta sensorial e dinâmica dos gases intestinais entre individuos com distensão abdominal funcional e voluntários assintomáticos, onde comparamos os efeitos da distensão retal sobre o trânsito de gás intestinal em pacientes com síndromes gastrointestinais funcionais e indivíduos saudáveis. Durante o meu estágio em Barcelona trabalhei em vários outros projetos, o que me proporcionou a publicação de três artigos em revistas de alto impacto científico.

Em 2007 realizei o pós-doutorado na Universidade de Harvard, em Boston, também com a concessão de uma bolsa do CNPq. No Hospital Beth Israel eu tive a oportunidade de trabalhar com diferentes linhas de investigação sob a orientação de dois excepcionais pesquisadores, Antony Lembo e Felipe Fregni. Com o Prof. Lembo realizei um trabalho de revisão de mais de 300 prontuários de pacientes com distúrbios funcionais digestivos, determinando fatores de gravidade e qualidade de vida desses pacientes, além de outro estudo sobre a prevalência de supercrescimento bacteriano em pacientes com síndrome do intestino irritável (dados ainda não publicados). Sob a orientação do Dr. Felipe Fregni, que é neurologista, foi iniciado um estudo para avaliar o efeito clínico da Estimulação Magnética Transcraniana em pacientes com distúrbios gastrointestinais funcionais, trabalho que ainda se encontra em fase de finalização. Conseguimos ainda realizar uma meta-análise sobre o tratamento da dispepsia funcional, comparando o efeito de medicamentos rotineiramente empregados com aqueles de ação central, sendo o artigo publicado na íntegra na revista Pain Physician há dois meses (CNS or classic drugs for the treatment of pain in functional dyspepsia? A systematic review and meta-analysis of the literature).

Durante o estágio no exterior, com todo o tempo disponível para a pós-graduação, praticamos verdadeira imersão na investigação científica, o que é formidável. Ao mesmo tempo, a visão de quem vive e estuda no exterior se amplia consideravelmente, o mesmo acontecendo com a capacidade de entender e interagir com diferentes culturas, novos amigos e novos idiomas. Para ficar um período no exterior é óbvio que alguns desafios, nem sempre fáceis, precisam ser vencidos, especialmente a saudade da família, dos amigos e da rotina da vida no Brasil. Viver em um país diferente significa uma série de mudanças em diversos aspectos da vida de qualquer pessoa.

Antes de se pensar em fazer um investimento em uma pós-graduação no exterior, o profissional deve analisar cuidadosamente sua área de atuação e a oportunidade real de sair do país. A seguir, abordaremos alguns aspectos práticos que devem ser lembrados para realmente valer a pena sair do Brasil.

1) Quando vale a pena fazer a pós-graduação fora do Brasil?

É importante ressaltar primeiramente que temos inúmeros cursos excepcionais de Pós-Graduação no Brasil, que em determinadas áreas não deixam nada a desejar aos programas acadêmicos de universidades do exterior.

- Se for um candidato ao mestrado não há nenhuma razão essencial para ir para o exterior. A maioria dos mestrados no Brasil bem avaliados pela CAPES são melhores do que os cursos ditos "mestrado" no exterior;

* Faculdade de Medicina da Universidade Federal de Minas Gerais, Belo Horizonte, MG. 
- Se for um candidato ao doutorado vale a pena sair do Brasil caso seja possível conseguir ser aceito em um centro de excelência exatamente na área de pesquisa desejada ou quando o tema de interesse não está disponível no nosso meio. Um bom doutorado no Brasil - com a previsão de um estágio no exterior (doutorado sanduíche) - pode ser boa alternativa, pois o tempo fora do país é menor, o que facilita o contato com a sociedade médica local;

- Em áreas com tradição de pesquisa mais consolidada os alunos terminam o doutorado no Brasil e, só depois, são considerados preparados para um pós-doutorado em um centro de pesquisa internacional. Neste caso, o objetivo é a experiência em outros ambientes e o estabelecimento ou manutenção de projetos conjuntos de pesquisa.

2) Como escolher a Universidade?

Definir a subárea de especialização;

- Definir a região geográfica de preferência;

- Escolher uma instituição ou universidade-padrão, reconhecida internacionalmente na área de interesse do candidato;

- Escolher um orientador com reconhecida experiência profissional, produção técnico-científica compatível com sua qualificação e real disponibilidade para o seu orientando;

- Verificar atentamente o programa da Pós-Graduação:

a) Qualificação dos pesquisadores;

b) Dedicação do corpo docente às atividades de ensino, pesquisa e orientação;

c) Se o tema da tese/projetos de pesquisa é realmente relevante;

d) Se a infra-estrutura do serviço (laboratórios, biblioteca, recursos de informática, etc.) é adequada para o desenvolvimento do trabalho.

No site da CAPES pode-se acessar uma pasta denominada AVALIAÇÃO que contém informações sobre inúmeros cursos fora do Brasil, com a opinião de professores e ex-alunos. São descritos os critérios de avaliação de cada programa e essa é uma excelente forma de se conhecer com detalhes a Pós-Graduação e a Universidade onde se pretende trabalhar.

3) Como encontrar meios financeiros para permanecer no exterior?

- Este é um dos principais aspectos a ser considerado. A principal fonte de recursos é o governo brasileiro através de

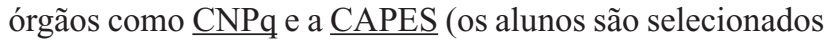
de acordo com o currículo e seu desempenho acadêmico);

- Existem inúmeros outros órgãos governamentais federais e estaduais, além de instituições privadas que também dispõem de recursos para auxiliar o pesquisador durante seu estágio no exterior;

- Algumas universidades e instituições de diversos países também concedem bolsas de estudos para o pesquisador brasileiro.

Para obtenção da bolsa de estudos, alguns pré-requisitos são exigidos pela maioria das instituições: a) proficiência no idioma do país de destino; b) ser brasileiro ou estrangeiro com visto permanente no Brasil; c) possuir titulo de mestre ou formação equivalente (para a bolsa de doutorado) ou de doutorado (para a bolsa de pós-doutorado); d) anuência formal da instituição de destino; e) concordância do orientador no exterior; f) ter vínculo empregatício no Brasil (pós-doutorado).

O planejamento para a escolha da pós-graduação é parte essencial e determinante para um futuro promissor no exterior. E esta não é uma decisão fácil pois, como vimos, existem diversos parâmetros a serem colocados na balança, antes de se definir pela viagem ao exterior. E esse planejamento para a pós-graduação pode ser resumido basicamente em três questões: onde? como? com quem? Escolher um orientador não é uma decisão isolada, é preciso escolher a instituição e encontrar meios financeiros para permanecer fora do Brasil.

Durante esse planejamento é fundamental a colaboração de professores e colegas com os quais trabalhamos no Brasil. Eu tive o privilégio de receber um valioso apoio e incentivo constante de dois grandes professores, Dr. Luiz de Paula Castro e Dr. Luiz Gonzaga Vaz Coelho. Como orientação à minha vida acadêmica, deles recebi o estímulo necessário para experimentar novas fronteiras do conhecimento, abrindo-se para mim as portas de um mundo novo.

Portanto, com planejamento cuidadoso, contribuição da família, amigos e da equipe de trabalho, a temporada fora do Brasil se torna um período especial e particular na vida do médico e/ou do pesquisador, sendo uma experiência enriquecedora em todos os sentidos, proporcionando-nos um aprendizado global. 